\title{
Surveillance Powers of Law Enforcement and Intelligence Services in Poland
}

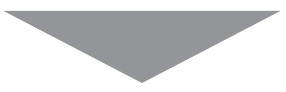

\begin{abstract}
The article presents three cases from 2018. They show that in Poland there is a tendency to build strengthened surveillance powers without finding a balance between security and respect for human rights. In the first case, the Commissioner for Human Rights withdrew his application from the Constitutional Tribunal (March 2018), in which he questioned the reforms introduced in 2016. According to the Polish Ombudsman, in the Polish legal system there is still a shortage of the legal safeguards which would make sure that surveillance measures do not violate fundamental rights. In the second case, the Prosecutor General submitted one application to the Constitutional Tribunal concerning the constitutionality of obtaining of evidence of the committing of another offence different from the one covered by operational surveillance. The third case concerns two new institutions which emerged in 2018, which were granted considerable powers in terms of surveillance: the National Security Services and the Internal Supervision Bureau, which is subject to the Ministry of Internal Affairs. The circumstances surrounding the emergence of these institutions will also be analyzed.
\end{abstract}

Keywords: state surveillance, intelligence services, intelligence reform, Poland, accountability 


\section{INTRODUCTION}

Surveillance measures are typical in the work of law-enforcement agencies and intelligence services. They make it possible to fight against such threats as terrorism, cyber-attacks, organized crime etc. However, these activities may also seriously interfere with some fundamental rights of citizens, in particular privacy and data protection. Nowadays technological advancements have generated new threats and, at the same time, have provided means of fighting those threats, making such work increasingly complex. Technological progress means that intelligence services have tools for almost unlimited surveillance. It follows that the obligation of a state authority in this sphere is to provide adequate safeguards for its citizens. Reforms in this area are needed not only in Poland but also in other EU countries which are also subject to criticism concerning their surveillance laws. ${ }^{1}$ In Poland there were no significant surveillance reforms in 2018. So why would an article about the lack of such reforms be important? The simplest answer to this question is this: the starting point of surveillance law at the beginning of 2018 in Poland was not satisfactory. ${ }^{2}$

The amendments to the Police Act of $1990^{3}$ implemented many recommendations included in the Constitutional Tribunal judgment of the $30^{\text {th }}$ of July $2014 .{ }^{4}$ However, the most essential principles formulated in the judgment, which had to be reflected in the process of the revision of surveillance law, were not included. In this judgment, the Tribunal specified essential principles that must be jointly met by provisions which regulate the obtaining of information on individuals in secrecy by public authorities in a democratic state ruled by law. The Polish legislator has not introduced any such principles to date. For example, according to the judgment the law should provide for the right of the monitored person to be informed about the surveillance of them once it is finished, and the right to initiate a judicial review thereof (however, in exceptional circumstances a depar-

1 See e.g. R. J. Aldrich, D. Richterova, Ambient Accountability: Intelligence Services in Europe and the Decline of State Secrecy, "West European Politics" 2018, vol. 41, no. 4, pp. 10031024; H. Born, M. Caparini, Democratic Control of Intelligence Services: Containing Rogue Elephants, Hampshire-Burlington: Ashgate, 2007; J. H. Diet rich, Of Toothless Windbags, Blind Guardians and Blunt Swords: The Ongoing Controversy about the Reform of Intelligence Services Oversight in Germany, "Intelligence and National Security" 2016, vol. 31, no. 3, pp. 397-415.

2 See A. Nyzio, Wokól „ustawy inwigilacyjnej”. Geneza, przepisy i konsekwencje Ustawy z dnia 15 stycznia 2016 r. o zmianie ustawy o Policji oraz niektórych innych ustaw, „Jagielloński Przegląd Bezpieczeństwa” 2017, no. 2 (1) and literature referenced in this article.

3 The Act of 15 January 2016 amending the Police Act and certain other acts.

4 The Constitutional Tribunal, Judgment of 30 July 2014 (no. K 23/11). 
ture from the notification rule should be possible). ${ }^{5}$ Such a right has not yet been granted to citizens.

A number of recommendations from the Venice Commission have not been introduced in Polish law. According to the Opinion of 2016, procedural safeguards and material conditions set in the police acts ${ }^{6}$ on implementing secret surveillance are still insufficient because they do not prevent excessive use of powers and unjustified interference in the privacy of individuals. Detailed recommendations of the Venice Commission concerned the strengthening of the proportionality principle in the following way: first, the limitation of the use of secret surveillance only to the most serious cases; secondly, the limitation of the duration of metadata monitoring. It is also important that respecting lawyerclient privilege (and other privileged communications) while ordering secret surveillance was mentioned. A number of recommendations concerned the mechanism of oversight of secret surveillance and metadata collection (to complement the system of judicial pre-authorization of secret surveillance with additional procedural safeguards, e.g. a privacy advocate, a complaints mechanism, a system of ex-post automatic oversight of such operations by an independent body). ${ }^{7}$

Many opinions regarding surveillance in the EU countries can be found in the reports of the European Union Agency for Fundamental Rights (FRA). ${ }^{8}$ The issue of the impact of surveillance on fundamental rights is crucial in democratic countries. One of the FRA reports makes, e.g. the following recommendations: a clear legal framework; defining in law the competencies of oversight bodiesover

5 See also: The Constitutional Tribunal, Decision of 25 January 2006 (no. S 2/06).

6 The term "the police acts" includes the act of the $6^{\text {th }}$ of April 1990 on the Police; the act of the $12^{\text {th }}$ of October, 1990 on the Border Guard; the act of the $24^{\text {th }}$ of August 2001 on the Military Police and military law enforcement bodies; the act of the $24^{\text {th }}$ of May 2002 on the Internal Security Agency and the Foreign Intelligence Agency; the act of the $9^{\text {th }}$ of June 2006 on the Central Anticorruption Bureau; the act of the $9^{\text {th }}$ of June 2006 on the Military Counterintelligence Service and the Military Intelligence Service; the act of the $16^{\text {th }}$ of November 2016 on the National Revenue Administration; and the act of the $8^{\text {th }}$ of December 2017 on the National Security Service.

7 Council of Europe, Venice Commission, Opinion on the Act of 15 January 2016 Amending the Police Act and Certain Other Acts, pp. 32-33, https://www.venice.coe.int/webforms/docu ments/default.aspx?pdffile=CDL-AD(2016)012-e (accessed March 17, 2019).

8 See e.g. European Union Agency for Fundamental Rights, Surveillance by intelligence services: fundamental rights safeguards and remedies in the EU. Volume I: Member States' legal frameworks, Luxembourg: Publications Office of the European Union, 2017; European Union Agency for Fundamental Rights, Surveillance by intelligence services: fundamental rights safeguards ad remedies in the EU. Volume II: field perspectives and legal update, Luxembourg: Publications Office of the European Union, 2017. 
international intelligence cooperation, efficient protection of whistleblowers, safeguards against surveillance for protected professions (e.g. members of parliament, members of the judiciary, lawyers and media professionals). These reforms should be introduced along with broad consultation and openness during the legislative process. A significant number of the recommendations concerned the oversight systems of intelligence services. The legal system should provide independent intelligence oversight with sufficient powers and competencies, technical expertise, openness to public scrutiny etc.

In the Polish case, the introduction of these recommendations would require fundamental systemic changes in surveillance and intelligence law. Such extensive reforms have been implemented in France, Germany, the Netherlands and the United Kingdom in recent years. ${ }^{9}$ In Poland there are no governmental proposals for such reforms although the program of the ruling PiS ('Law and Justice') party assumes the strengthening of parliamentary oversight of intelligence services and the adoption of comprehensive surveillance law. ${ }^{10}$ Neither the program nor the governmental policy links the surveillance issue to the protection of individual rights. Poland is definitely going in a different direction, by strengthening the surveillance powers of the security services without material and procedural safeguards for fundamental rights. This article will present three cases from 2018. They show that in Poland there is a tendency to build strengthened surveillance powers without finding a balance between security and respect for human rights.

In the first case, the Commissioner for Human Rights withdrew his application from the Constitutional Tribunal (March 2018), in which he questioned the reforms introduced in 2016. ${ }^{11}$ According to the Polish Ombudsman, in the Polish legal system there is still a shortage of the legal safeguards which would make sure that surveillance measures do not violate fundamental rights. However, the Ombudsman stated that there was no chance of independent and substantive judgment of the Constitutional Tribunal. The main reasons were changes in structure and personnel of the Tribunal after controversial reforms after 2016.

In the second case, the Prosecutor General submitted one application to the Constitutional Tribunal concerning the constitutionality of art. 168b of the Code of Criminal Procedure (July 31, 2018). This provision concerns the obtaining of

9 European Union Agency for Fundamental Rights, Surveillance by Intelligence Services: Fundamental Rights Safeguards and Remedies in the EU. Volume II..., p. 9.

10 Program Prawa i Sprawiedliwości 2014. Zdrowie. Prawa. Rodzina, p. 62, http://pis.org.pl/doku menty (accessed March 19, 2019).

11 The Commissioner for Human Rights, application no. K 9/16. 
evidence of the committing of another offence different from the one covered by operational surveillance. In this case it is crucial to understand what the concept "another offence" means. The Prosecutor General claims that "another offence" means all offences - if operational surveillance has provided evidence of a different crime (any offence), or one committed by a different person (any person), the prosecutor shall take a decision as to whether to use this evidence in criminal proceedings. According to the Resolution of the $28^{\text {th }}$ of June 2018 of the Supreme Court, "another offence" means a catalog of crimes for which operational surveillance could belegally applied. These are only serious offences, mainly crimes. ${ }^{12}$ The Prosecutor General does not accept such a narrow understanding of the concept.

The third case concerns two new institutions which emerged in 2018, which were granted considerable powers in terms of surveillance: the State Protection Service (established on the $1^{\text {st }}$ of February 2018 to replace the Government Protection Bureau), and the Internal Supervision Bureau, which is subject to the Ministry of the Interior and Administration. The second institution is supposed to keep other services under surveillance by request of the Minister of the Interior and Administration. The circumstances surrounding the emergence of these institutions will also be analyzed in the following.

\section{CASE NO. 1}

In March 2018 the Commissioner for Human Rights withdrew his application from the Constitutional Tribunal in which he questioned the reforms introduced in 2016. The reform significantly extended the surveillance powers of law enforcement agencies and intelligence services. That is why in February 2016 the Polish Ombudsman questioned the most important provisions of the amendment to the Constitutional Tribunal. According to him, the reform not only fails to execute the judgment of the Constitutional Tribunal of 2014, but "seriously violates the constitutional rights and freedoms and the standards set out in international law". ${ }^{13}$

12 According to article 7 of the Polish Penal Code: The offence is either a crime or a misdemeanor $(\$ 1)$. The crime is a prohibited act subject to penalty of imprisonment of not less than 3 years or to a more severe penalty $(\$ 2)$. A misdemeanor is a prohibited act subject to the penalty of a fine higher than 30 times the daily fine, the penalty of restriction of liberty or the penalty of deprivation of liberty not exceeding one month (\$3).

13 The Commissioner for Human Rights application no. K 9/16, p. 6. 
The most important allegations included in the application concerned the violation of the right to privacy and the protection of the personal data of citizens:

- The lack of a time limit, or the disproportionately long duration of operational surveillance (named in the official English translation of the police acts as "operational control"). Operational surveillance is a power of the police and intelligence services which includes such measures as listening to and recording the contents of telephone conversations and correspondence conducted via telecommunication networks (e-mails, messengers, etc.), in ordinary letters or recorded "live" conversations with listening devices, etc. Therefore, operational surveillance allows these services to know the content of communications assumed to be private by those involved in them. ${ }^{14}$ Operational surveillance is performed, as a rule, with the prior consent of a regional court. ${ }^{15}$ This power can be prolonged to a maximum of 18 months. This is too long a time period for the Ombudsman, and in his opinion it does not satisfy the condition of the proportionality principle. The Ombudsman questions the fact that for one and a half years the services may listen in on people or read their correspondence - regardless of whether criminal proceedings will be initiated on this basis.

- The very broad mandate of police and intelligence services to collect metadata. Metadata is all data connected to and regarding a (tele-)communication. It may include information about phone calls placed or received, numbers dialed, duration of calls, geographical location of mobile devices at a given moment, websites visited, login details, personal settings, addresses of e-mail correspondence etc. ${ }^{16}$ This power gives police and intelligence services the opportunity to reveal considerable information about a person's private life. The grounds for collecting metadata under the police acts are very wide. Services may collect metadata for any useful purpose related to their very broad mandate to maintain peace and order. ${ }^{17}$ Metadata may be obtained without prior consent of a court or another independent body external to police and intel-

14 See Council of Europe, Venice Commission, op. cit., p. 7.

15 In "cases of the utmost urgency, where any delay could result in the loss of information or the obliteration or destruction of the evidence of a crime", police may start surveillance without prior consent of the court but with the authorization of a prosecutor. If consent is not granted within the following 5 days, surveillance must be suspended and the material obtained must be destroyed.

16 See Council of Europe, Venice Commission, op. cit., p. 7.

17 E.g. under Article 20c para. 1 of the Police Act, the Police can obtain metadata "in order to prevent or detect crimes or in order to save human life and health, or in order to support search and rescue missions". 
ligence services. Moreover, metadata collection does not have to be related to criminal proceedings. According to the Ombudsman, such a very broad mandate for the collection of metadata leads to the risk of abusive surveillance being employed: metadata can be collected not only when it is necessary but also when it is just convenient for the services.

- No real oversight of metadata collection by an independent body. Regarding the collection of metadata, there is only a system of ex-post review in Poland. The police acts require police and intelligence services to submit, to competent regional courts, biannual reports containing generalized information about the metadata collected during a given period of time. According to the Ombudsman, courts do not have all the necessary legal tools with which to fulfill their controlling function. The reporting obligation is insufficient because reports contain only summarized information, which does not give insight into the particulars of each specific case. That is why the system of expost review provides only illusory oversight.

- The lack of the right of a monitored person to be informed about surveillance. As already noted above, such a right has not yet been granted to citizens. According to the current provisions a citizen does not receive such information, even when no evidence was detected during the surveillance.

- Flaws in the provisions regulating the surveillance of privileged communications. The Ombudsman in his application drew particular attention to the weaker professional privilege which covers notaries, advocates and legal advisors (who do not act as defense lawyers), tax advisors, doctors, mediators or journalists. Nothing in Polish law prevents the police and intelligence services from listening to such conversations. Moreover, the court must allow recordings of such conversations as evidence if two conditions are met: first, it is "necessary from the viewpoint of the justice system"; second, when there are no other means of establishing the facts of the case available. The concept of the "viewpoint of the justice system" is blurred. It is necessary for the Ombudsman to reflect on a more stringent rule which would describe the circumstances in which privileged professional communications may be secretly recorded and then introduced as evidence.

The allegations of the Commissioner for Human Rights are based on the caselaw of the European Court of Human Rights, Court of Justice of the EU and the Polish Constitutional Tribunal ${ }^{18}$ The case-law of these courts is essentially convergent. Therefore, the allegations are very similar to the recommendations of

18 The Constitutional Tribunal, Judgment of 12 December 2005 (no. K 32/04). 
the Venice Commission. Nota bene: the Venice Commission, "in deference to the Constitutional Tribunal", avoided commenting on the compatibility of the 2016 amendments with the Polish Constitution and based its analysis on international standards. ${ }^{19}$

The key issue here is to determine the reason for the Ombudsman's withdrawal of his application. As noted above, he stated that there was no chance of independent and substantive judgment of the Constitutional Tribunal. Primarily (before the changes in Tribunal), the Ombudsman's application was due to be recognized by the Constitutional Tribunal in full panel (at least 11 out of 15 judges). Later, structural and personnel changes in the Constitutional Tribunal influenced the manner in which application was considered. In January 2017 the President of the Constitutional Tribunal, Julia Przyłębska, decided that the case would be examined by a panel of five. The Ombudsman drew attention to the lack of a legal basis for the change in the composition of the Tribunal in this case. Moreover, the judges elected - in violation of the constitution - were members of the panel of five judges. At this point, there is no need to delve into this legal dispute - it is clear that the application of the Ombudsman would be considered by a panel of five judges of the Tribunal instead of full branch. The majority of the judges in this branch were selected after the controversial reforms of the Constitutional Tribunal by the current government.

The withdrawal of the application for the above reasons is very significant if we take into account the role of the Constitutional Tribunal in limiting the powers of surveillance. Until now it has been one of the key institutions in the system of oversight of the police and intelligence services. The jurisprudence of the Constitutional Tribunal has often contributed to changes of surveillance law in the direction of the introduction of procedural and material safeguards for human rights.

\section{CASE NO. 2}

On the $31^{\text {st }}$ of July 2018 the Prosecutor General submitted one application to the Constitutional Tribunal concerning the constitutionality of art. 168b of the Code of Criminal Procedure. ${ }^{20}$ As to the substance, he proposes to literally understand

19 See Council of Europe, Venice Commission, op. cit., p. 5.

20 This provision was introduced by the Act of the $11^{\text {th }}$ of March, 2016 amending the Act - Code of Criminal Procedure and some other acts. 
this provision - if operational surveillance provided evidence of a different crime or one committed by a different person, the prosecutor shall take a decision as to whether to use this evidence in criminal proceedings. In this case, the catalog of crimes is no limitation as to when operational surveillance could be legally enforced. This opinion includes all offences prosecuted ex officio or fiscal offences - be they serious, very serious or minor. This means wider possibilities in the use of surveillance powers.

The application of the Prosecutor General includes, besides the legal arguments, a proposal regarding the vision of criminal policy. Political arguments are more important for understanding why he is in favor of increasing surveillance powers. The most important of them are presented below:

- Surveillance powers as an effective tool of the state to fight and prevent crime. In the application, the confidentiality of these powers is defined as their primary advantage. ${ }^{21}$ The perspective of the state is visible in this statement, and not the individual's perspective.

- Trust in the state. The police and intelligence services may have broad powers, because they will be used against criminals and not "ordinary" citizens. The state must prevent and prosecute crimes in the name of the common good and the interests of victims of crime. ${ }^{22}$ The common good can only be represented by a state that can effectively administer justice - only such a state can induce citizens' trust. ${ }^{23}$ Essentially, since we already have evidence of a crime, we must use it. If law enforcement does not use them for only formal reasons, then it limits trust in the state. According to the application, such a state deprives itself of effective tools with which to fight crime and becomes an additional burden on citizens. ${ }^{24}$

- A catalog of offences as protection of the criminal. According to the Prosecutor General, we cannot limit the possibility of using evidence of offences. A limit (e.g. the catalog of offences for the monitoring of which operational surveillance may be legally enforced) means promoting the reprehensible behavior of a citizen disloyal to the community at the expense of others - loyal citizens. ${ }^{25}$

- Focus on the offender. A person, against whom evidence of an offense has been gathered, is just an offender. Such a person has no right to privacy

\footnotetext{
21 The Prosecutor General's application (no. K 6/18), p. 9.

22 Ibidem, p. 28.

23 Ibidem, p. 33.

24 Ibidem.

25 Ibidem, p. 66.
} 
because he or she stands against the community and does not fulfill their basic constitutional duty - to observe the law. ${ }^{26}$ If we have evidence, then the offender must be held criminally liable. ${ }^{27}$

- Victim of an offence. Almost any offence involves the harming of a person a victim of an offence. A task of the state is to guarantee the victim that the offender will be held criminally liable. ${ }^{28}$ In addition, the state is obliged to ensure that everyone shall respect the freedoms and rights of others.

The General Prosecutor's application presents the powers of operational surveillance from the perspective of the state, specifically its law enforcement agencies. Surveillance is simply an effective tool with which to fight crime and we should not limit such tools. It is also specifically limited to focusing only on criminals and victims.

Another perspective is presented in the application of the Ombudsman regarding this provision. ${ }^{29} \mathrm{His}$ application focused on the protection of individual rights. The possibility of using evidence gathered by surveillance without limitation creates the risk of law enforcement agencies acting arbitrarily. The provisions covering criminal liability should be more precise from the perspective of individual rights. In addition, such powers of the state authorities require the creation of an effective and independent oversight system.

It is clear that the two perspectives presented above are very different. Now the Constitutional Tribunal will have to settle the Prosecutor General's application. In this situation the Tribunal will decide on whether or not to extend the state's powers of surveillance.

26 In accordance with article 31 para 2 Polish constitution: "Everyone shall respect the freedoms and rights of others. No one shall be compelled to do that which is not required by law. In accordance with article 83 of the Polish constitution: Everyone shall observe the law of the Republic of Poland".

27 The Prosecutor General's application (no. K 6/18), p. 32.

28 Ibidem, p. 65.

29 See The Commissioner for Human Rights' application, no. K 24/16.This also withdrew his application from the Constitutional Tribunal. 
CASE NO. 3

In 2018 two new institutions emerged which were granted considerable powers in terms of surveillance: the State Protection Service (in Polish: Służba Ochrony Państwa, SOP) which was established on the $1^{\text {st }}$ of February, 2018 and replaced the Government Protection Bureau (in Polish: Biuro Ochrony Rządu, BOR) as well as the Internal Supervision Bureau (in Polish: Biuro Nadzoru Wewnętrznego), which is subject to the control of the Ministry of the Interior and Administration.

The SOP, just like the Government Protection Bureau, is responsible for providing VIP security services for the Polish government (security of incumbent and former Presidents of Poland, high-ranking state officials etc.). However, the new service has gained much wider powers. Controversy was aroused by the granting of surveillance powers to the SOP, because the BOR did not have such powers. The surveillance powers of the SOP are wide and include operational surveillance and the collection of metadata. It is particularly worth noting that the draft law copied solutions of other police acts without any new proposals for better safeguards for human rights. This draft law was criticized for two reasons. ${ }^{30}$ Firstly, the SOP should not have any surveillance powers at all because such powers are not needed for the performance of its tasks. ${ }^{31}$ Secondly, surveillance powers should be limited by better safeguards for human rights. The frequently mentioned safeguards in the context of this draft law were as follows: - providing real control over the collection of metadata ${ }^{32}$;

- limiting arbitrariness in collecting metadata - the principle of subsidiary ${ }^{33}$;

- an obligation to inform (ex post) a person about the use of operational surveillance. ${ }^{34}$

These safeguards were proposed by, e.g., the Ombudsman and the Venice Commission regarding the police acts. They are based on the case law of the Constitutional Tribunal and the European Court of Human Rights. Finally, no new mechanisms were introduced to the Act. From the point of view of protect-

30 Approval for the act: see J. Wy re mbak, Opinia prawna dotyczaca rzadowego projektu ustawy o Stużbie Ochrony Państwa (druk sejmowy nr 1916), Warsaw 2017.

31 Opinion of the Panoptykon Foundation on the draft law on the National Security Service, p. 2.

32 Opinion of the Supreme Court on the draft law on the National Security Service, p. 4; Opinion of the Panoptykon Foundation..., p. 5

33 Opinion of the Supreme Court..., p. 5.

34 Opinion of the Panoptykon Foundation..., p. 4; see the Constitutional Tribunal, Decision of 25 January 2006 (no. S 2/06). 
ing human rights, or not, the State Protection Service is another agency authorized to carry out surveillance on people. This shows the lack of willingness to improve surveillance law.

In late 2017 and early 2018 another agency - the Internal Supervision Bureau - was established. On the $27^{\text {th }}$ of January 2018 the first head of this institution was appointed. The Internal Supervision Bureau is specific - it is a part of the Ministry of the Interior and Administration and is supposed to keep under surveillance other services upon the request of the Minister of the Interior and Administration. The purpose of this service is to improve and unify ministerial control of other services: the Police, the Polish Border Guard and the State Protection Service. One of the tasks of the new agency is control of the surveillance activities of the above-mentioned services. Seconded police officers, border guards and SOP officers work primarily in the Internal Security Bureau. Formally, this institution is a part of the internal organization of the Ministry of Interior.

The wide surveillance powers of the Internal Security Bureau are controversial. Since 1990 - when civil control over security services was established - only the services (the Police, the Polish Border Guard, intelligence services etc.) have had surveillance powers. Prior to this Police forces and intelligence services were a part of the ministries, which were highly centralized, hierarchized and party-dependent. The police acts of 1990 completely reshaped the structure of the Ministry of Internal Affairs. It was divided into civil and political Ministry of Internal Affairs as well as politically neutral departments subject to the control of the minister. However, the new structure also singled out a few autonomous central authorities: the chief constable, the chief of the Office for State Protection and the chief of the Border Guard. Thereafter the Minister of Internal Affairs was responsible for the protection of state safety. However, neither he nor his office would be directly involved in commanding the services or carrying out surveillance. Since this time the burden of running the Office for State Protection (in Polish: Urząd Ochrony Państwa), the Police and the Polish Border Guard has fallen on the chiefs of these organizations. The Minister had the right to interfere only when he was entitled to do so by the applicable acts. This solution was designed to separate civil and political management in the ministry from professional and apolitical services. Until now, control over surveillance powers has belonged to prosecutors and courts.

The surveillance powers of the new services under the control of the Ministry of Internal Affairs work against the above-mentioned model. On the one hand, the Minister of the Interior gets the opportunity to view the surveillance materials of the subordinate services. On the other, his service - The Internal Security 
Bureau - also has wide surveillance powers. For example, this institution can use operational surveillance or collecting metadata.

Surveillance methods form the core of the activity of each service. The problem of monitoring this activity is visible in many countries. However, the common standard is oversight exercised by an independent, external body. The appointment of the Internal Security Bureau does not meet this standard. The Ministry of Internal Affairs is politically accountable for the activities of the services controlled by it (the Police, the Polish Border Guard, the National Security Bureau). That is why a reliable explanation of violations may conflict with the minister's potential accountability. This lack of independence concerns the principles of secondment to serve in the Internal Security Bureau. Dismissal from the post may take place at any time. The consequences of such an arrangement may be the unwillingness of officers to undertake certain official activities for fear of being dismissed from the post. To sum up, in order to prevent violations in the functioning of the services, the minister was given the opportunity to influence the substantive (surveillance) activities of the supervised formations. 35 people are to serve in the Internal Security Bureau. It is debatable whether it was necessary to deconstruct the existing control system in order to enable 35 officers to perform their duties, especially since no previous attempt had been made to improve the system.

\section{CONCLUSiOnS}

In 2018 there were no significant reforms in Poland which increased the safeguards of individual rights regarding state surveillance. This status quo is far from the standard set by the Constitutional Tribunal and the European Court of Human Rights. In addition, personnel and organizational changes in the Constitutional Tribunal have made it difficult to predict the development of its further case-law. In 2018 the Polish Ombudsman withdrew a number of his applications to the Constitutional Tribunal, including applications related to surveillance. The intentions of his decisions are important. The Ombudsman withdrew his applications regarding surveillance not because the law has been corrected and already provides basic safeguards of individual rights. The reason is different he stated that there was no chance of independent and substantive judgments of the Constitutional Tribunal. However, the Tribunal will consider the application of the General Prosecutor. This is interesting because he claims that the police 
and intelligence services should have wide surveillance powers. In his opinion it is unconstitutional to over-limit the possibilities of services in this area. Until now, the Constitutional Tribunal's case law has significantly reduced surveillance powers and was of major importance for statutory changes in the matter of surveillance when it comes to increasing safeguards of individual rights.

The government's surveillance policy of last year was not linked to the protection of individual rights. Surveillance powers are treated by the government only as an effective tool with which to fight crime. This approach was evident when the National Security Service was given very wide surveillance powers. The BOR - the predecessor of the SOP - had no surveillance powers. In this case there is a visible tendency for a multiplication of the services authorized to use surveillance powers. This has been a problem since the early 1990s. The newly established services keep getting extensive surveillance powers. There is a lack of deeper reflection on the relationship between these powers and the tasks of the individual services.

In 2018, surveillance became not only an effective tool for the services, but also a tool that politicians could use. This has involved the establishment of the Internal Security Bureau in the Ministry of the Interior and Administration. Formally, the Bureau is the internal structure of the ministry. In fact, it has the same surveillance powers as police and intelligence services. Nota bene: the Internal Security Bureau can apply surveillance powers to the services subordinate to the Minister of the Interior and Administration (the Police, the Polish Border Guard and the SOP). This means that surveillance activities of these services are available to a politician - the Minister of the Interior and Administration. ${ }^{35}$ This arrangement does not create a system of independent control over surveillance.

35 This is the second politician that affects surveillance powers. According to the new Law on the Prosecutor's Office (Act of 28 January 2016 Law on Prosecutor Office, "Journal of Laws" 2017, item 1767 as amended) the office of the Prosecutor General is held by the Minister of Justice. This is especially important because prosecutors are also entitled to give permission for the use of some surveillance methods. 


\section{BIBLIOGRAPHY}

Act of 28 January 2016 Law on Prosecutor Office, "Journal of Laws" 2017, item 1767 as amended.

Aldrich, R. J., Richterova, D. Ambient Accountability: Intelligence Services in Europe and the Decline of State Secrecy, "West European Politics" 2018, vol. 41, no. 4, https:/doi. org/10.1080/01402382.2017.1415780.

Born, H., Caparini, M. Democratic Control of Intelligence Services: Containing Rogue Elephants, Hampshire-Burlington: Ashgate, 2007.

Council of Europe, Venice Commission, Opinion on the Act of 15 January 2016 Amending the Police Act and Certain Other Acts, https://www.venice.coe.int/webforms/doc uments/default.aspx?pdffile=CDL-AD(2016)012-e (accessed March 17, 2019).

Dietrich, J. H. Of Toothless Windbags, Blind Guardians and Blunt Swords: The Ongoing Controversy about the Reform of Intelligence Services Oversight in Germany, "Intelligence and National Security” 2016, vol. 31, no. 3, https://doi.org/10.1080/02684527.2 015.1017246.

European Union Agency for Fundamental Rights, Surveillance by Intelligence Services: Fundamental Rights Safeguards and Remedies in the EU. Volume I: Member States' Legal Frameworks, Luxembourg: Publications Office of the European Union, 2017. European Union Agency for Fundamental Rights, Surveillance by Intelligence Services: Fundamental Rights Safeguards ad Remedies in the EU. Volume II: Field Perspectives and Legal Update, Luxembourg: Publications Office of the European Union, 2017.

Nyzio, A. Wokół „ustawy inwigilacyjnej”. Geneza, przepisy i konsekwencje Ustawy z dnia 15 stycznia 2016 r. o zmianie ustawy o Policji oraz niektórych innych ustaw, „Jagielloński Przegląd Bezpieczeństwa” 2017, no. 2 (1).

The Constitutional Tribunal, Judgment of 12 December 2005 (no. K 32/04).

The Constitutional Tribunal, Judgment of 30 July 2014 (no. K 23/11).

The Constitutional Tribunal, Decision of 25 January 2006 (no. S 2/06).

Program Prawa i Sprawiedliwości 2014. Zdrowie. Prawa. Rodzina, http://pis.org.pl/dokumenty (accessed March 19, 2019).

Wyrembak, J. Opinia prawna dotyczacca rzadowego projektu ustawy o Służbie Ochrony Państwa (druk sejmowy nr 1916), Warszawa 2017. 